\title{
Hubungan Keterbukaan Diri dengan Interaksi Sosial Peserta Didik di Sekolah Menengah Pertama Minhajuth Thullab Way Jepara Lampung Timur
}

\author{
Laila Maharani, Latifatul Hikmah
}

\author{
Dosen dan Mahasiswa Fakultas Tarbiyah dan Keguruan, IAIN Raden Intan Lampung
}

Diterima: Oktober 2015. Disetujui: November 2015. Dipublikasikan: Desember 2015

\begin{abstract}
Abstrak: Metode penelitian ini menggunakan penelitian kuantitatif korelasi dengan pendekatan cross sectional. Populasi penelitian adalah kelas VII Integral Minhajuth Thullab junior sejumlah 70 siswa maka teknik simple yang digunakan adalah purposive sampling, sampel dipilih sebanyak 24 siswa kelas VIIB. Teknik pengumpulan data yang digunakan adalah kuesioner, observasi dan wawancara. Hasil penelitian menunjukkan $20(83,3 \%)$ siswa memiliki interaksi sosial rendah dan ada 18 siswa $(75,1 \%)$ yang memiliki sikap tertutup. Sedangkan siswa pserta $(16,7 \%)$ yang memiliki interaksi sosial tinggi. Hasil analisis menunjukkan bahwa ada hubungan yang signifikan antara keterbukaan diri dengan interaksi sosial siswa kelas VIIB. Saran yang diajukan oleh peneliti untuk sekolah adalah untuk memudahkan kebutuhan peserta didik dan bimbingan konseling guru untuk merekomendasikan ruang untuk melakukan sesi konseling guna membantu peserta didik. Dan terutama bagi guru bimbingan dan konseling agar bisa membuat program bimbingan bimbingan konseling, terutama masalah personal dan sosial baik oleh personal maupun group service.
\end{abstract}

Kata Kunci: Keterbukaan diri, Interaksi Sosial, Peserta Didik

\section{Pendahuluan}

Kita sadari, pada hakikatnya manusia adalah makhluk sosial, dan dalam kehidupan sehari-hari kita ada banyak interaksi sosial dan pengaruh dan orang lain dan amat sulit jika membayangkan jika keberadaannya tidak melibatkan kontak dengan orang lain (Matsumoto, 2008). Akan tetapi, individu juga akan menghadapi berbagai tantangan dan perubahan kehidupan dan tak pernah lepas dari sebuah masalah. Dalam hali ini konseling menjadi alternatif penting dalam membantu individu memecahkan masalahnya (Erhamwilda, 2009). Dalam hal kepribadian, hal ini dijelaskan dalam teori Carl Jung yang mendiskripsikan karakteristik utama manusia, karakteristik diapandang sebagai lawan dan perangkat pertamanya adalah sikap eksrtavert dan introvert. Ekstravet merupakan sepereti halnya keterbukaan diri yaitu kecenderungn untuk melihat dunia luar, khususnya oranng lain, demi kesenangan diri. Orang-orang dengan karakteristik ekstravert biasanya mudah bersahabat dan menikmati aktivitas sosial, tetapi merasa tidak nyaman ketika sendirian.

Sedangkan inrovert merujuk pada sebuah kecenderungan untuk mengutamakan dunia didalam diri seseorang. Aspek-aspek introvert adalah malu, tidak suka pada fungsi-fungsi sosial, dan menyukai privasi (Boeree, 2007). Tipe kepribadian introvert yang menjadi parasit bagi setiap individu karena tipe ini akan mengakibatkan meghilangnya kesempatan anak untuk belajar sosial, sehingga sosialisasi mereka semakin jauh lebih rendah dibandingkan denga teman seusianya. Jika perilaku mereka lebih rendah dari harapan sosial, anak dinilai kurang baik. Semakin jauh anak berada dibawah standard dan harapan kelompok sosial, semakin merugikan penyesuain diri dan sosial mereka akan semakin kurang pula konsep diri mereka (Boeree, 2007). Berkomunikasi merupakan kebutuhan penting untuk menjalani interaksi dalam hubungan interpersonal. Interaksi dalam hubungan interpersonal tersebut dapat terjalin dengan siapa saja meliputi teman akrab (sahabat), orang tua/saudara, teman biasa, maupun kenalan (Rahmawati, 2014).

Person mengartikan self disclosure sebagai tindakan seseorang dalam memberikan informasi yang bersifat pribadi pada orang lain secara sukarela dan disengaja untuk maksud memberi informasi yang akurat tentang dirinya. (Ifdil, 2013). Wrightsman mengemukakan keterbukaan diri atau self disclosure adalah proses mnghadirkan diri yang diwujudkan dalam 
kegiatan membagi perasaan dan informasi dengan orang lain. Dengan begitu, interaksi antar individu dengan orang lain, apakah orang lain akan menrima atau menolak, bagaimana mereka ingin orang lain mengetahui tentang mereka ingin orang lain mengetahui tentang mereka akan ditentukan oleh bagaimana individu dalam mengugkapkan dirinya.

Sedangkan menurut Morton keterbukaan diri merupakan kegiatan membagi perasaan dan informasi yang akrab dengan orang lain. Informasi di dalam keterbukaan diri bersifat deskritif atau evaluatif. Deskritif artinya individu melukiskan berbagai fakta mengenai diri sendiri yang mungkin belum diketahui oleh pendengar seperti jenis pekerjaan, alamat dan usia. Sedangkan evaluatif artinya individu mengemukakan pendapat atau perasaan pribadinya seperti tipe orang yang disukai atau hal-hal yang tidak disukai atau dibenci (Hidayat, 2012).

Keterbukaan diri sebagai pemberian informasi tentang diri sendiri kepada orang lain. Informasi ini dapat mencakup berbagai hal seperti pengalaman hidup, perasaan, emosi, pendapat, cita-cita, dan sebagainya. Pengetahuan tentang diri akan meningkatkan komunikasi dan pada saat yang berkomunikasi dengan orang lain akan dapatmeningkatkan pengetahuan diri sendiri. Menurut Johnson terdapat beberapa manfaat dan dampak keterbukaan diri terhadap hubungan antar individu yaitu sebagai berikut: (1) Keterbukaan diri merupakan dasar bagi hubungan yang sehat antara dua orang (2) Semakin kita besikap terbuka kepada orang lain, semkain orang lain tersebut akan menyukai diri kita, akibatnya ia akan semakin membuka diri kepada kita (3) Orang yang rela membuka diri kepada orang lain terbukti cenderung memiliki sifat sebagia berikut, kompeten, terbuka, ekstorvert, fleksibel, adaptif, dn inteligen (4) Keterbukaan diri kepada orang lain merupakan dasar relasi yang memungkinkan komunikasi intim baik dengan diri kita sendiri maupun dengan orang lain; dan (5) Keterbukaan diri sama dengan sikap realistik (Supratiknya, 2012). Keterbukaan diri amat besar pengaruhnya dalam hubungan sosial yang efektif.

Kemampuan sosialisasi penting untuk diteliti karena kemampuan sosialisasi penting untuk diteliti karena kemampuan sosialisai dibutuhkan oleh semua individu untuk saling berinteraksi satu sama lain. Kemampuan sosialisasi sangat menentukan bagaiamana cara untuk bersikap, menyampaikan informasi tentang dirinya (self disclosure). kemampuan sosialisasi sangat menentukan bagaimana cara untuk bersikap, menyampaikan informasi tentang dirinya (self disclosure), maka dia akan mengalami kesulitan berkomunikasi dengan orang lain. Misalnya dalam lingkungan sekolah banyak dijumpai adanya sikap kurang terbuka antara peserta didik dengan guru, dan peserta didik dengan teman- temannya (Sania N. Hanifa, desember 2012). Menurut Sania N Hanifa Sugiyo dan Ninik Setiawati mengemumakan pendapatnya bahwa peserta didik yang memiliki keterbukaan diri rendah akan memiliki karakteristik sebagai berikut: 1) kesulitan untuk menyesuaikan diri; 2) pemalu; sulit berkomunikasi; 4) pesimis; 5) tidak bisa mengeluarkan pendapat; dan 6) memiliki sikap curiga yang tinggi terhadap orang lain (susah untuk percaya) (Sania N. Hanifa, desember 2012).

Sesuai dengan perkembangannya, remaja dituntut lebih belajar menyesuiakan diri dengan lingkungan sosial yang lebih luas dan majemuk. Apabila remaja tersebut tidak memiliki kemampuan self disclosure, maka dia akan mengalami kesulitan berkomunikasi dengan orang lain. Dengan memiliki pengungkapan diri yang tepat seorang peserta didik akan lebih mampu untuk mengatasi ketidaknyamanan yang mengganggunya untuk bisa berkembang secara optimal.

Berdasarkan beberapa penelitaian yang terkaiit dengan penelitian ini antara lain yaitu, Lintang Dewi Saputri, Endang Triyanto dan Keksi Gerindra Swasti yang meneliti "Hubungan Kemampuan Sosialisasi dengan Keterbukaan diri siswi kelas VII" dengan subyek kelas VII SMP Giripuro Sumpiuh dengan ketentuan kriteria peneliti. Hasil penelitian menunjukan adanya hubungan secara signifikan antara kemampuan sosialisasi dengan keterbukaan diri. Hal tersebut terlihat pada hasil uji Fisher Exact diperoleh nilai x2 hitung adalah 9,565 lebih besar 58 
dari nilai $\mathrm{x} 2$ tabel $(5 \%)=9,488$ atau nilai $\mathrm{p}=0,005<0,05$. Selain penelitian tersebut terdapat pula penelitian dari Sania N. Hanifa, Sugiyo dan Ninik Setiyowani yang berjudul "Meningkatkan Keterbukaan Diri dalam Komunikasi Antar Teman Sebaya Melalui Bimbingan Kelompok Teknik Johari Window" dengan subyek penelitian siswa SMA Walisingo Pecangaan Jepara pengumpulan data dengan skala psikologi. Hasil penelitian menunjukan hasil keterbukaan diri meningkat setelah memperoleh bimbingan kelompok dengan teknik johari window. Hal ini dibuktikan dengan hasil uji wilcoxon Thitung=55,0 dan Ttabel= 8,0 yang berarti Ha diterima dan Ho ditolak.

\section{Metode Penelitian}

Teknik sampling yang akan digunakan oleh peneliti adalah Purposive sampling. Teknik ini penentuan sampel dengan menggunakan pertimbangan tertentu. Maka pada penelitian ini sampel yang akan diteliti oeleh peneliti yaitu kelas seluruh kelas VIIB yang berjumlah 24 peserta didik. Populasi yang akan diteliti oleh peneliti adalah seluruh kelas VII yang berjumlah 70 peserta didik yang terdiri dari kelas VII A, B, dan C tahun pelajaran 2014/2015. Jenis penelitian yang akan peneliti lakukan adalah penelitian kuantitatif korelasi.

Penelitian korelasi menggambarkan suatu pendekatan umum untuk penelitian yang berfokus pada penaksiran pada kovariasi diantara variabel yang muncul secara alami. Tujuan penelitian korelasional adalah untuk mengidentifikasi hubungan prediktif dengan menggunakan teknik korelasi. Penelitian menggunakan teknik korelasional dengan rancangan lintas seksional (cross sectional design).

Menurut Emzir rancangan lintas seksional (cross sectional design) berfokus pada pendeskripsikan karakteristik dari suatu populasi atau perbedaan antara dua atau lebih populasi pada satu titik waktu. Pendeskripsikan perubahan pada sikap atau opini pada waktu yang lama (panjang) memerlukan penggunaan rancangan sampel bebas suksesif atau rancangan longitudinal (Emzir, 2010). Adapun penelitian ini peneliti membahas "Hubungan keterbukaan diri dengan interakasi sosial peserta didik di MTs Minhajuth Thullab Way Jepara Lampung Timur pada tahun pelajaran 2014/2015”.

\section{Hasil dan Pembahasan}

Pada penelitian ini peneliti memilih responden yang memiliki tingkat Sekolah Menengah Pertama (SMP) dikarenakan pada masa tersebut merupakan masa transisi yang memilikji tantangan sosial, perubahan kehidupan dan tak pernah lepas dari sebuah masalah bahkan pada masa ini anak bisa saja bersikap anti sosial dan menutup diri. Keterbukaan diri menurut Johnson yaitu mengungkapkan perasaan atau informasi yang dialami individu secara sukarela terhadap orang lain. Seperti halnya dijelaskan oleh Dasrun Hidayat bahwa kertbukaan diri atau kemampuan untuk membuka diri melalui informasi yang diberikan kepada orang lain dapat meningkatkan keakraban, kepercayaa diri, dan kekeluargaan. Apabila seseorang bersikap tertutup maka individu akan menunjukan sikap kurang percaya diri, merasa tidak aman, tidak dapat mengekspresikan pikiran dan perasaannya secara bebas.

Keterbukaan diri yang terjadi pada responden dapat diketahui dengan memberikan angket responden, dari angket yang telah diberikan kepada responden maka tingkat keterbukaan diri peserta didik diketahui dari 24 peserta didik yang dijadikan sampel dalam penelitian ini, terdapat 18 peserta didik yang berada pada kelompok tertutup dari perhitungan presentase sebesar $75,1 \%$ dan terdapat 6 peserta didik yang memiliki sikap terbuka dari presentasi sebesar $25,1 \%$. Dengan begitu perlunya upaya bagi guru BK dalam menangani masalah yang terkait dengan keterbukaan peserta didik. Guru BK di SMP Minhajuth Thullab 
juga mengemukakan pendapatnya bahwa peserta didik kelas VIIB jarang bahkan tidak pernah mengunjungi guru BK.

Dengan begitu, peneliti dapat menyimpulkan bahwa sikap tertutup rata-rata masih dimiliki peserta didik di kelas VIIB SMP Integral Minhajuth Thullab. Hal ini dibuktikan dengan hasil penelitian ynag telah dilakukan. Interaksi sosial yang terjadi pada responden dapat diketahui dengan memberikan angket kepada responden, dari angket yang diberikan kepada responden, maka interaksi sosial dapat diketahui dari 24 peserta didik yang dijadikan sampel dalam penelitian ini, terdapat 20 peserta didik yang memeiliki interaksi sosial yang rendah dariperhitungan presentase sebesar $83,3 \%$ dan terdapat 4 peserta didik yang interaksi sosialnya tinggi dari presentasi 16,7\%. Brehm dan Kassin mengemukakan ciri-ciri interaksi sosial yang baik antara satu sama lain terhubung secara emosional, satu sama lain mampu memenuhi kebutuhan, dan satu sama lain tergantung dan pengaruh mempengaruhi.

Dari uraian diatas dapat dimengerti bahwa interaksi sosial yang tinggi belum dimiliki oleh peserta didik di kelas VIIB Minhajuth Thullab Way Jepara Lampung Timur yang dibuktikan oleh hasil penelitian yang telah menjelaskan bahwa peserta didik yang mengalami masalah interaksi sosial yang sebesar 20 peserta didik atau 83,3\%. Berbeda dengan remaja yang mampu melakukan keterbukaan diri, mereka dapat berbagi dan mencari jawaban tentang suatu hal yang harus dilakukan sehingga mereka akan terhindar dari masalah psikologis maupun fisologis.

Dalam pencarian identitas inilah mereka harus memiliki interaksi sosial yang baik untuk membuka diri, karena pengetahuan tentang diri akan meningkatkan komunikasi dan pada saat yang sama berkomunikasi dengan orang lain dapat meningkatkan pengetahuan diri sendiri (Lintang Dewi Saputri, 2012) hal tersebut terjadi pada kelas VIIB SMP Integral Minhajuth Thullab Way Jepara Lampung Timur hal ini terlihat bahwa peserta didik yang tergolong tertutup memeiliki presentasi $75,1 \%$ dan yang terbuka $25,1 \%$. Lalu interaksi sosial yang rendah memeliki presentasi $83,3 \%$ dan yang ringgi $16,7 \%$ yang membuktikan sikap anti sosial dan menutup diri pada peserta didik terjadi pada kelas VIIB SMP Integral Minhajuth Thullab. Selain itu, data tersebut juga membuktikan bahwa kedua variabel antara keterbukaan diri dnegan interkasi sosial memiliki hubungan yang signifikan.

\section{Simpulan dan Saran}

Dari penelitian yang telah dilakukan peneliti maka dapat disimpulkan bahwa SMP Integral Minhajuth Thullab kelas VIIB, Peserta didik yang tergolong tertutup memiliki presentasi $75,1 \%$ dan yang terbuka $25,1 \%$. Lalu interaksi sosial yang rendah memeliki presentasi $83,3 \%$ dan yang ringgi $16,7 \%$ yang membuktikan bahwa terdapat hubungan yang signifikan antara ketrbukaan diri dengan interaksi sosial peserta didik ( $p$ - value $=0,001$ yang berarti $\mathrm{p}<\alpha$ ). 


\section{Daftar Pustaka}

Boeree, C. G. (2007). General psychology, Psikologi Kepribadian, Persepsi, Kognisi, Emosi \& Perilaku. Yogyakarta: Ar-Ruzz Media Group.

Emzir. (2010). Metodologi Penelitian pendidikan Kuantitatif \& Kualitatif Korelasional, Eksperimen, Ex Post facto, Etonografi, Grounded Theory, Action Research. Jakarta: RajaGrafindo Persada.

Erhamwilda. (2009). konseling islami. Yogyakarta : Graha Ilmu.

Erhamwilda. (2009). Konseling Islami. Yogyakarta: Graha Ilmu.

Hidayat, D. (2012). Komunikasi Antar Pribadi dan Medianya Fakta Penelitian Fenomenalogi Orang Tua Karir Anak Remaja. Yogyakarta: Graha Ilmu.

Ifdil. (April 2013). Konsep dasarSelf Disclosure Dan Pentingnya Bagi Mahasiswa Bimbingan Dan Konseling. Jurnal Ilmiah Ilmu Pendidikan Pedagogi. Vol. XIII. No. 1, 111.

Lintang Dewi Saputri, E. T. (2012). Hubungan Kemampuan Sosialisasi dengan keterbukaan Diri Siswa Kelas VIII. Jurnal Keperawatan Soedirman (The Soedirman Journal of Nursing) .

Matsumoto, D. (2008). Pengantar Psikologis Lintas Budaya . Yogyakarta : Pustaka Pelajar.

Sania N. Hanifa, S. d. (desember 2012). Meningkatkan Keterbukaan Diri Dalam Komunikasi Antar Teman Sebaya Melalui Bimbingan Kelompok Teknik Johari Window. Indonesian Journal of guidance and counseling thoery and application Unes , 55.

Supratiknya, A. (2012). Tinjauan Psikologis Komunikasi Antarpribadi. Yogyakarta: Penerbit Kansius.

Ummi Mafthukhah Rahmawati, S. Kontribusi Penerimaan teman sebaya Terhadap Pengungkaan.

Ummi Mafthukhah Rahmawati, S. (2014). Kontribusi Penerimaan Teman Sebaya Terhadap Pengungkapan Diri Siswa Kelas VIII SMP Negeri 1 Masaran. Jurnal Program Bimbingan dan Konseling Jurusan Ilmu Pendidkan FKIP Universitas Sebelas Maret, 4.Sugiyono. 2011. Metode Penelitian Pendidikan Pendekatan Kuantitatif, Kualitatif, dan R\&D. Bandung : Alfabeta. 
